\title{
The orchid Ophrys speculum Link (Orchidaceae) in Croatia
}

\author{
Nina Vuković ${ }^{1 *}$, AnNAlisa TOMmasoni $^{2}$, TANCREDi D'ONOFriO $^{2}$ \\ ${ }^{1}$ University of Zagreb, Faculty of Science, Division of Biology, Department of Botany \\ with Botanical Garden, Marulićev trg 20/II, HR-10000 Zagreb, Croatia \\ ${ }^{2}$ Pendice Scoglietto 5, IT-34127 Trieste, Italy
}

\begin{abstract}
The orchid Ophrys speculum Link is widely distributed in the Mediterranean. Since its inclusion in the checklist of Croatian flora, the species has not been confirmed in the field, but has recently been found on Cape (rt) Kamenjak, southern Istria. A few plants were growing within garrigue vegetation of Cisto-Ericetalia.
\end{abstract}

Keywords: Ophrys speculum, orchid, Rt Kamenjak, Istria, Croatia

\section{Introduction}

In Croatian flora the genus Ophrys is present with 67 taxa, the largest genus in terms of number of taxa from the Orchidaceae family (HRŠAK 2000, BOGDANOvić 2004, NiKOLIĆ 2012). The genus is distributed throughout the whole of Croatia, but more taxa can be found in the Mediterranean part, as the genus is principally Mediteranean (DELFORGE 2006).

The Ophrys speculum group consists of three closely related species: $O$. speculum Link, $O$. vernixia Brotero and O. regis-ferdinandii (Achtaroff et Kellerer ex Renz) Buttler (Greuter 2004, Delforge 2006). Ophrys speculum is a widespread Mediterranean species commonly found (sometimes even abundantly) in many Mediterranean countries (e.g. Spain, Greece, North Africa), but rare in the centre of the range (Soó 1980, PignATTI 1982, DELFORGE 2006). For example, the species is noted for France and Corsica, but it appears to be extremely rare on the mainland (LePAGE and Wilcox 2003, Delforge 2006). Similarly, O. speculum is found only sporadically on the Italian mainland, but is common on Sicily and Sardinia (Pignatti 1982, Romolini and Biagioli 2002, Delforge 2006). Two variants can be distinguished across the distributional range of the species; the western variant $O$. speculum Link ssp. speculum and the eastern variant with darker flowers, O. speculum Link

* Corresponding author, e-mail: nina.vukovic@biol.pmf.hr

Copyright ${ }^{\circledR} 2013$ by Acta Botanica Croatica, the Faculty of Science, University of Zagreb. All rights reserved. 
ssp. orientalis (Paulus) Paulus et Salkowski (BAumann et al. 2006, Delforge 2006, PAUlus and SALKOWSKI 2007).

It flowers in the period of (February-) March-April (-May) and inhabits open habitats with full sunlight to mid shade, such as poor grassland and garrigue, appearing mostly in coastal areas up to $1200 \mathrm{~m}$ asl. (DELFORGE 2006). The species is pollinated by the wasp Dasyscolia ciliata (Scoliidae, Hymenoptera) and this relationship is highly species-specific (Pouyanne 1917, Ayasse et al. 2003, Baumann et al. 2006, Paulus 2007). It has been found that the western variant is pollinated by $D$. ciliata ssp. ciliata, while the eastern variant is pollinated by D. ciliata ssp. araratensis (DELFORge 2006, PAUlus and SALKOWSKI 2007).

Although O. speculum is listed in the checklist of the Croatian flora (HRŠAK 2000, NiKOLIĆ 2012) no specific locality is given, and furthermore, the origin of the data is unknown. Relevant determination keys do not mention the eastern Adriatic coast as a part of the species range (Soó 1980, BAumANn et al. 2006, DELFORge 2006).

The cape of the Istrian peninsula (Rt Kamenjak, north Adriatic) has been protected since 1996, nowadays as a part of the Significant Landscape »Lower Kamenjak and Medulin archipelago «. More than 500 plant taxa have been recorded in previous floristic studies (Tommasini 1873; Freyn 1877; Perko 1998; StARmüHLER 1998, 2004, 2010; Topić and ŠEGULJA2000; HRŠAK et al. 2011), some of them rare, endangered and/or endemic; therefore Rt Kamenjak has recently been estimated as an Important Plant Area (Vuković 2010). A former study of orchids of the same area (VuKović et al. 2011) did not provide any note on O. speculum.

\section{Materials and methods}

The area of Rt Kamenjak was surveyed during May 2010 when a few plants were found in the field. We used the relevant determination key for European orchids (DELFORGE 2006) for determination of the species. The same area was surveyed again in April 2012, with one fieldtrip in the first, and other in the second half of the month. On the second fieldtrip, the exact position of the locality was determined using GPS Garmin eTrex Vista, and the checklist of the adjacent flora was prepared. The obtained coordinates of the field observation were incorporated into the Flora Croatica Database (Nikolić 2012) and a distribution map was prepared using ESRI GIS ArcMap 9.3 software. The nomenclature of taxa is given according to BAUMANN et al. (2006), PAULUS and SALKOWSKI (2007) and Flora Croatica Database (NIKOLIĆ 2012).

In addition to fieldwork, two herbarium collections (ZA and ZAHO) were examined for specimens and some old literature was searched for localities of O. speculum (VISIANI 1842, 1847, 1852; Schlosser and Vukotinović 1869; Pospichal 1897; ManNagetTa 1901; ADAMOVIĆ 1909; Rossi 1924, 1930; HAYEK 1933).

Furthermore, O. speculum was evaluated under the IUCN criteria (GÄRDENFORS et al. 2001, ANONYMOUs 2010) to obtain the threat status of the species on the national level.

\section{Results}

Three individuals of Ophrys speculum ssp. speculum (Fig. 1) were found growing along the macadam road on the way to Cape Škara on south-eastern Kamenjak (13 ${ }^{\circ} 54^{\prime} 55^{\prime \prime}$ N, 

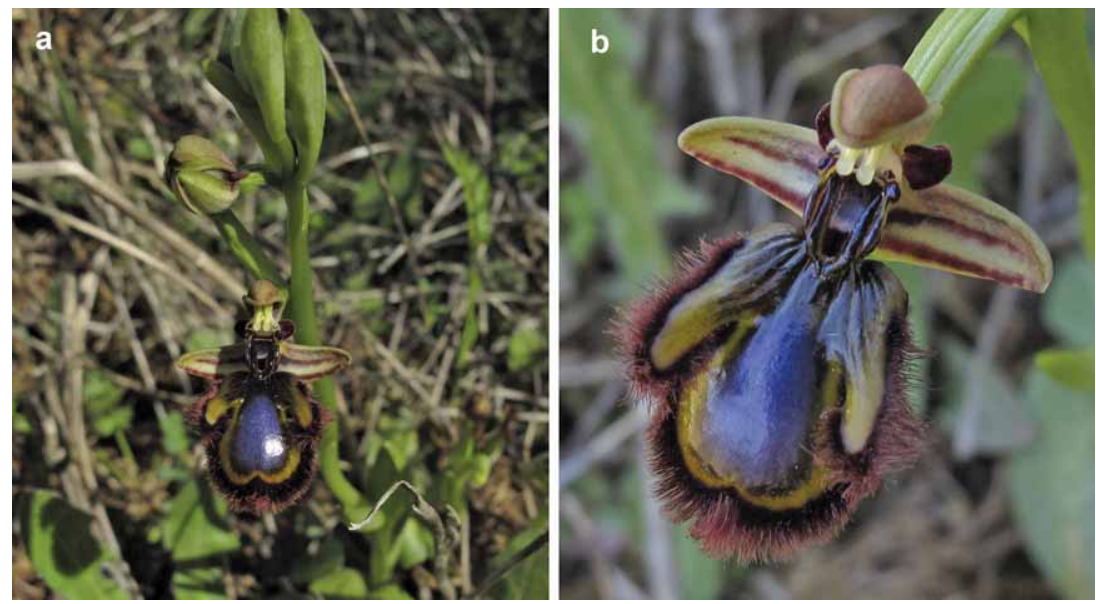

Fig. 1. Ophrys speculum Link ssp. speculum. a - habitus, b - flower (Photo by Nina Vuković).

444'ㅇ" E) (Fig. 2). The road passes through garrigue vegetation of the order Cisto-Ericetalia H-ić. 1958. In the first half of April only the sprouts were observed, while in the second half the plants were fully flowering. The plants were up to $10 \mathrm{~cm}$ high but generally in a good condition. However, the evaluation of the threat status on the national level has resulted in proposing the species as CR D (critically endangered according to criteria D). Accompanying plant species typical of the area were recorded in the close vicinity, given alphabetically in the following list: Cerastium pumilum Curtis ssp. glutinosum (Fries) Jalas,

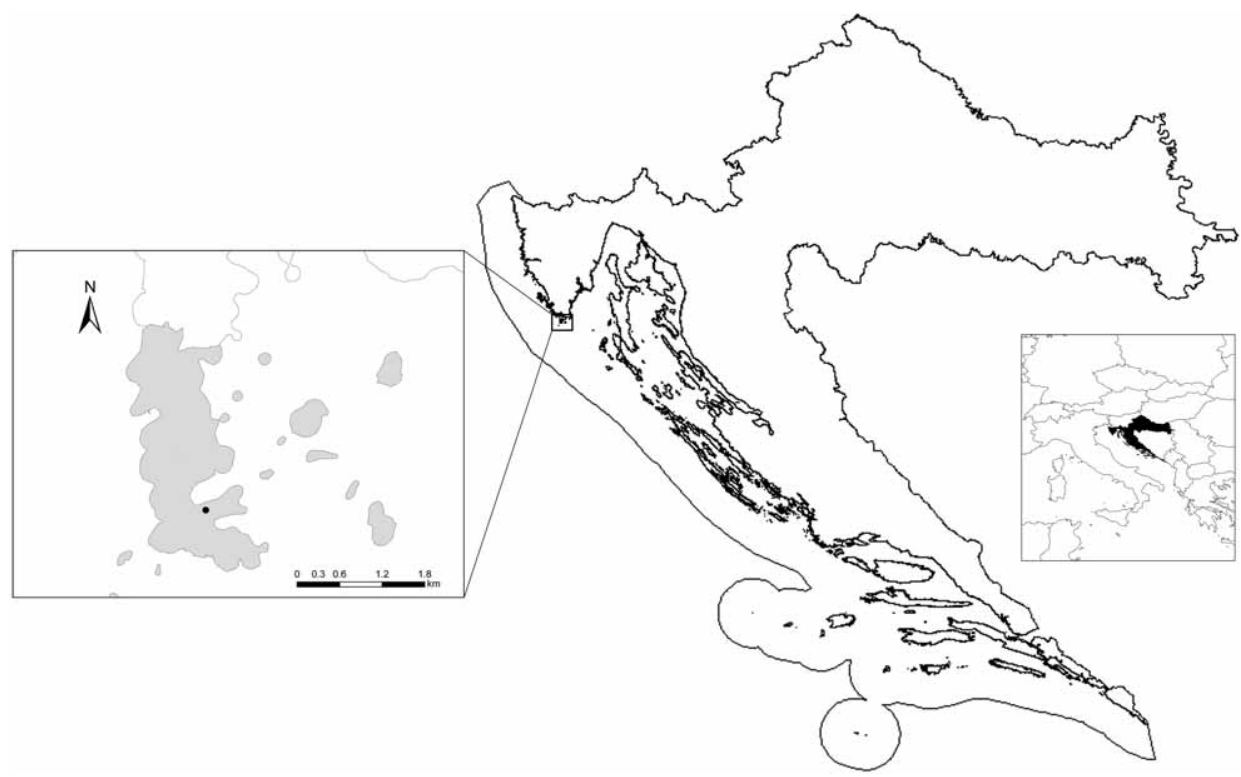

Fig. 2. Locality of Ophrys speculum Link ssp. speculum on Rt Kamenjak. Gray area - Lower Kamenjak and Medulin archipelago«. 
Convolvulus arvensis L., Dittrichia viscosa (L.) Greuter, Dorycnium hirsutum (L.) Ser., Helichrysum italicum (Roth.) G. Don, Hypericum perforatum L., Juniperus oxycedrus L., Orchis morio L., Plantago coronopus L., Plantago lanceolata L., Sanguisorba minor Scop. ssp. muricata Briq., Sherardia arvensis L. and Spartium junceum L.

The search within the ZA and ZAHO herbaria did not reveal any specimens of $O$. speculum. None of the reviewed literature references provided any note on O. speculum in Croatia.

\section{Discussion}

The species Ophrys speculum was found within its usual Mediterranean range, growing in a typical habitat and our finding is in accordance with the steno-Mediterranean distribution of this species. Therefore an even wider occurrence of this species in Croatia could be expected. However, it is evident that $O$. speculum is extremely rare in Croatia. Possible confusion with other Croatian orchids due to morphological similarity is excluded because of the rather specific morphology of its flowers, such as large, shiny lip with dense, brown hairs (Fig. 1), which makes it easily identifiable. The only similar plants are two related species from the same group that are rarer than O. speculum and locally distributed (O. vernixia in Portugal and Spain, O. regis-ferdinandii in Greece and Anatolia). What is more, they can be distinguished from $O$. speculum by the shape of the labellum and its lobes (BAUMANN et al. 2006, DELFORGE 2006). The rather early flowering period of the species and the fact that it can flower sporadically (DELFORGE 2006) could be a part of the explanation.

The scarce presence of this species in Croatia, as well as in Italy and France, is most probably connected with the distribution of a specific pollinator wasp Dasyscolia ciliata. Recent data (FALLAHZADEH and SAGHAEI 2010, OSTEN 2012) show that the wasp is absent from France, Italy and eastern-Adriatic coast, with a confirmed presence in the Portuguese mainland, Spanish mainland, Balearic Islands, Greek mainland, Dodecanese Islands, Malta, North Africa and the Near East. In addition, existing data show the presence of D. ciliata on Corsica, Sicily and Sardinia (COCQUEMPOT and HARMOn 1995, Osten 2000, PAGLiAnO 2012).

In the key for Scoliidae from OSTEN (2000) there is an indication that the wasp can be found in Croatia and/or nearby countries, stating that the wasp is present on the eastern Adriatic coast, but this probably refers to the record of MAIDL (1922), who mentions $D$. ciliata (as Scolia ciliata) for 'Durazzo' (Durrës, Albania). To date there has been no record of the presence of this wasp in Croatia.

From the available distributional data for O. speculum and D. ciliata it can be concluded that the range of the orchid, where it is widespread and common, mainly corresponds to areas with the confirmed presence of the wasp. Since the plant-pollinator relationship is highly species-specific in the case of Ophrys orchids (PAULUs 2007), the absence or scarce presence of the wasp in the range of Ophrys speculum could prevent or seriously reduce the ability of the orchid to reproduce and therefore close its life-cycle. Consequently, its occurrence in Croatia is unusual and it is likely to be found only accidentally and no stabile occurrence is to be expected.

The localized distribution of this orchid in Croatia (only one confirmed population of three individuals), the vicinity of the road (potential threat from passengers and/or vehicles) and exposure to natural succession certainly amplify the risk of disappearance from the 
area. Given all these facts, we conclude that there is an extremely high risk of extinction of O. speculum from the Croatian flora, and as a result recommend the species to be classified as Critically Endangered.

\section{Aknowledgements}

The file containing the borders of Croatian protected areas was provided by the State Institute for the Protection of Nature. The authors would like to thank Dr Sandro Bogdanović and Igor Boršić for useful comments on the manuscript, and also Vedran Šegota for help in the making of the digital distribution map.

\section{References}

AdAmović, L., 1909: Die Vegetationsverhältnisse der Balkanländer (Moesische Länder) umfassend Serbien, Altserbien, Bulgarien, Ostrumelien, Nordtrakien und Nordmazedonien. Wilhelm Engelmann, Leipzig.

ANONYMOUS, 2010: Guidelines for using the IUCN Red list categories and criteria, 8.1. Retrieved July 17, 2012 from http://intranet.iucn.org/webfiles/doc/SSC/RedList/RedList Guidelines.pdf

Ayasse, M., Schiestl, F. P., Paulus, H. F., Ibarra, F., Francke, W., 2003: Pollinator attraction in a sexually deceptive orchids by means of unconventional chemicals. Proceedings of the Royal Society B 270, 517-522.

Baumann, H., Künkele, S., Lorenz, R., 2006: Orchideen Europas. Mit angrenzenden Gebieten. Eugen Ulmer KG, Stuttgart.

Bogdanović, S., 2004: Orchidaceae. In: Bogdanović, S., Nikolić, T. (eds.), Notulae ad Indicem Florae Croaticae 4. Natura Croatica 13, 407-420.

Cocquempot, C., Hamon, J., 1995: Capture de Dasyscolia ciliata (Fabricius, 1787) en Corse-du-Sud (Hymenoptera, Scoliidae). Bulletin de la Société entomologique de France 100, 276.

Delforge, P., 2006: Orchids of Europe, North Africa and the Middle East. Timber Press, Oregon.

Fallahzadeh, M., Saghaei, N., 2010: A brief study on the Scoliidae in Iran (Insecta: Hymenoptera). Munis Entomology and Zoology 5, 792-795.

FreYN, J., 1877: Die Flora von Süd Istrien. Verhandlungen der Zoologisch-Botanischen Gesellschaft in Wien 27, 241-490.

Gärdenfors, U., Hilton-Taylor, C., Mace, G. M., Rodríguez, J. P., 2001: The Application of IUCN Red list criteria at regional Levels. Conservation Biology 15, 1206-1212.

GReuter, W., 2004: Proposal to conserve the name Ophrys speculum (Orchidaceae) with a conserved type. Taxon 53, 1070-1071.

HAYEK, A., 1933: Prodromus Florae peninsulae Balcanicae 3. Repertorium specierum novarum regni vegetabilis $30,1-472$.

HrŠAK, V., 2000: Orchidaceae. In: NiKolić, T. (ed.), Flora Croatica. Index Florea Croaticae 3. Natura Croatica 9, Supplement 1, 163-173. 
HrŠak, V., Brana, S., Sedlar, Z., PejIć, I., 2011: Morphometric and molecular (RAPD) analysis of six Serapias taxa from Croatia. Biologia 66, 55-63.

LePage, J. M., Wilcox, Y., 2003: Découverte d'Ophrys speculum Link 1800 (=Ophrys ciliata Bivona-Bernardi 1806) dans le Sud de la Vendée littorale. Le Naturaliste Vendéen 3, 105-106.

MAIDL, F., 1922: Beiträge zur Hymenopterenfauna Dalmatiens, Montenegros und Albaniens. Annalen des Naturhistorischen Museums in Wien 35, 36-106.

MAnNAGETtA, B. G. von, 1901: Die Vegetationsverhältnisse der illyrischen Länder. Wilhelm Engelmann, Leipzig. 1-534.

Nikolić, T. (ed.), 2012: Flora Croatica Database. Department of Botany and Botanical Garden, Faculty of Science, University of Zagreb. Retreived May 2012 from http://hirc.botanic.hr/fcd

Osten, T., 2000: Die Scoliiden des Mittelmeer-Gebietes und angrendzender Regionen (Hymenoptera). Ein Bestimmungsschlüssel. Linzer Biologische Beiträge 32, 537-593.

Osten, T., 2012: Dasyscolia ciliata. In: Mitroiu, M. D. (ed.), Fauna Europaea, Hymenoptera. Fauna Europaea ver. 2.4. Retrieved July 17, 2012 from http://www.faunaeur.org.

PAulus, H. F., 2007: Wie insecten-Männchen von Orchideenblütten getäuscht werden Bestäubungstricks und Evolution in der mediterranen Ragwurzgattung Ophrys. Denisia 20, Neue Serie 66, 255-294.

PAulus, H. F., SAlKOWSKI, H.-E., 2007: Bestäubungsbiologische Untersuchungen an Winterorchideen auf der Ägäis-Insel Kos (Orchidaceae und Insecta, Hymenoptera, Apoidea). Berichte aus den Arbeitskreisen Heimische Orchideen 24, 4-30.

Pagliano, G., 2012: Hymenoptera Scoliidae. In: Stoch, F. (ed.), Fauna Italia ver. 2.0. Italian Ministry of Environment. Retrieved July 17, 2012 from http://www.faunaitalia.it.

PERKO, M., 1998: Ergänzungen zur Flora von Istrien (Kroatien/Hrvatska): Serapias istriaca M. L. Perko, spec. nov. und Serapias x pulae M. L. Perko, nothospec. nov. (Orchidaceae). Berichte aus den Arbeitskreisen Heimische Orchideen 15, 13-27.

PignAtTi, S., 1982: Flora d'Italia, 3. Edagricole, Bologna.

Pospichal, E., 1897: Flora des Oesterreichischen Küstenlandes 1. Franz Deuticke, Leipzig and Wien. 1-575.

Pouyanne, M., 1917: La fécondation des Ophrys par les insectes. Bulletin de la Société d'Histoire Naturelle de l'Afrique du Nord 8, 6-7.

Rossi, LJ., 1924: The records for the flora of southern Croatia (In Croatian). Prirodoslovna istraživanja Kraljevine Jugoslavije 15, 1-217.

Rossi, LJ., 1930: The overview of the flora of Croatian littoral (In Croatian). Prirodoslovna istraživanja Kraljevine Jugoslavije 17, 1-368.

Romolini, R., Biagioli, M., 2002: La presenza di Ophrys ciliata Biv. in Toscana. Giros Notizie 20, 2-4.

Schlosser, J. C. K., Vukotinović, LJ., 1869: Flora Croatica. Sumptibus et auspiciis academiae scientiarum et articum slavorum meridionalium, Zagreb. 1-1362.

STARMÜHLER, W. (ed.), 1998: Vorarbeiten zu einer »Flora von Istrien« 1. Carinthia II $188 / 108,535-576$. 
STARMÜHLER, W. (ed.), 2004: Vorarbeiten zu einer »Flora von Istrien« 7. Carinthia II 194/ $114,591-651$.

STARmÜHLER, W. (ed.), 2010: Vorarbeiten zu einer »Flora von Istrien« 13. Carinthia II 200/ $120,465-524$.

Topić, J., ŠEgUlJA, N., 2000: Floristic and ecological characteristics of the southernmost part of Istria (Croatia). Acta Botanica Croatica 59, 179-200.

Soó, R., 1980: Ophrys L. In: Tutin, T. G., Heywood, V. H., Burges, N. A., Moore, D. M., Valentine, D. H., Walters, S. M., Webb, D. A. (eds.), Flora Europaea 5, 344-349. Cambridge University Press, Cambridge.

Tommasini, M. R., 1873: Die Flora des südlichsten Theiles von Istrien bei Promontore und Medolino. Oesterreichische Botanische Zeitschrift 23, 169-177, 219-227, 257-260.

Visiani, R., 1842: Flora Dalmatica 1. Apud Fridericum Hofmeister, Lipsiae, 1-252.

VISIANI, R., 1847: Flora Dalmatica 2. Apud Fridericum Hofmeister, Lipsiae, 1-268.

VISIANI, R., 1852: Flora Dalmatica 3. Apud Fridericum Hofmeister, Lipsiae, 1-390.

Vuković, N., 2010: Rt Kamenjak. In: Nikolić, T., Topić, J., Vuković, N. (eds.), Important plant areas of Croatia (In Croatian), 374-378. Prirodoslovno-matematički fakultet, Školska knjiga, Zagreb.

Vuković, N., Brana, S., Mitić, B., 2011: Orchid diversity of the cape of Kamenjak (Istria, Croatia). Acta Botanica Croatica 70, 23-40. 